\title{
PENERAPAN PROSES KEPERAWATAN DALAM PEMENUHAN \\ PERSONAL HYGIENE PADA PASIEN
}

\author{
SRI HARVITA SARI MARPAUNG/181101125
}

$\underline{\text { Sriharvitaaasm11@gmail.com }}$

\begin{abstract}
ABSTRAK
Dalam dunia kesehatan tujuan yang paling diutamakan adalah derajat kesehatan pasien semakin tinggi tingkat kesehatan pasien berarti semakin berkualitas pelayanan kesehatan yang diberikan. Dalam meningkatkan kesehatan pasien salah satu faktor pendukung adalah personal hygiene yang dimiliki oleh pasien, maka dalam pemberian asuhan keperawatan kepada pasien seorang perawat harus mampu membantu pasien yang memilih masalah dalam pemenuhan personal hygienenya sesuai dengan prinsip proses keperawatan. Dalam melakukan asuhan keperawatan perawat harus mampu mempertimbangkan hal - hal menyangkut pasien sehingga dalam prosesnya tidak terjadi hal yang tidak diinginkan dan tujuan untuk meningkatkan derajat kesehatan, memelihara kebersihan diri seseorang, memperbaiki personal hygiene yang kurang, pencegahan penyakit, meningkatkan kepercayaan diri seseorang, serta menciptakan keindahan.
\end{abstract}

Kata kunci : personal hygiene, proses keperawatan, perawat.

\begin{abstract}
In the world of health the most important goal is degree of health of the patien the higher the level of health of the patient means the more quality of health services provided. In improving patient health one of the supporting factors is personal hygiene which is owned by the patient, so in providing nursing care to patients a nurse must be able to help patients who choose problems in fulfilling personal hygiene in accordance with the principles of the nursing process. In conducting nursing care nurses must be able to consider matters relating to patients so that in the process does not occur that undesirable things and aims to improve the degree of health, maintain personal hygiene, improve personal hygiene, prevent disease, increase one's confidence, and create beauty.
\end{abstract}

Keywords : personal hygiene, nursing process, nurses.

\section{LATAR BELAKANG}

Personal hygiene adalah suatu tindakan untuk memelihara kebersihan dan kesehatan seseorang untuk kesejahteraan fisik dan psikis. Tujuan dari perawatan personal hygiene adalah untuk meningkatkan derajat kesehatan, memelihara kebersihan diri seseorang, memperbaiki personal hygiene yang kurang, pencegahan penyakit, meningkatkan kepercayaan diri seseorang, serta menciptakan keindahan (Tarwoto \& Wartonah, 2012). 
Sesuai dengan Potter \& Perry (2013) jika pasien tidak mampu melakukan personal hygiene maka tugas seorang perawat adalah memberikan bantuan dalam melaksanakan pemenuhan kebutuhan personal hygiene pasien. Salah satu bentuk perawatan diri adalah pemenuhan kebutuhan manusia. Perawat memiliki peran untuk memenuhi kebutuhan dasar manusia meliputi aspek biologi, sosial, dan spiritual. Personal hygiene sangat dipengaruhi oleh nilai individu dan kebiasaan sehingga personal hygiene merupakan hal yang penting dan harus diperhatikan karena personal hygiene akan mempengaruhi kesehatan dan psikis seseorang (Tarwoto \& Wartonah, 2012).

Tindakan personal hygiene merupakan salah satu yang harus dilakukan perawat terhadap klien yang meliputi kebersihan mulut, kebersihan mata, kebersihan telinga, kebersihan hidung, kebersihan mulut dan gigi, kebersihan kuku dan kaki (Hidayat, 2014). Peran perawat dalam hal ini sangat dibutuhkan untuk meningkatkan personal hygiene pasien baik melalui penyuluhan dan meningkatkan pengetahuan tentang upaya kebersihan diri dengan prinsip hidup sehat dan bersih. Perawat sebagai pemberi asuhan keperawatan dalam personal hygiene maka harus melakukan sesuai dengan prinsip proses keperawatan sehingga hasil yang diinginkan dapat tercapai dan dapat meningkatkan kesehatan pasien.

\section{TUJUAN}

Tujuan dari penulisan ini adalah untuk mengetahui penerapan proses keperawatan pada pasien yang memiliki masalah dalam pemenuhan personal hygienenya.

\section{METODE}

Metode yang digunakan pada penulisan ini adalah literature riview berdasarkan text book, jurnal, $e$ - book (10 tahun terakhir) dengan cara menganalisis, eksplorasi sumber, dan kajian bebas.

\section{HASIL}

Hasil yang didapatkan dari penulisan ini adalah mengetahui penerapan proses keperawatan dalam pemenuhan personal hygiene yang ditujukan kepada pasien untuk membantu pasien dalam pemenuhan kebutuhan dasarnya yang bertujuan meningkatkan derajat kesehatan pasien. 


\section{PEMBAHASAN}

Asuhan

keperawatan/proses

keperawatan pasien/klien yang memiliki masalah dengan personal hygienenya meliputi :

\section{Pengkajian}

Pengkajian perawat tentang personal hygiene yang meliputi kulit, kaki dan kuku, rambut, gigi dan mulut, mata, hidung, telinga, genitalia, pakaian, dan juga waktu mandi pasien. Pasien yang tidak melakukan kebersihan diri pada saat dirawat di rumah sakit maka akan menimbulkan masalah pada kesehatannya, karena pada konsepnya kebersihan sangat berpengaruh dalam masa pemulihan pasien di rumah sakit. Pengkajian yang dilakukan perawat adalah memeriksa apakah ada masalah dalam personal hygiene pasien, setelah ditemukan maka perawat bertanggungjawab untuk membantu pasien untuk melakukan perawatan diri. Identifikasi yang dilakukan perawat dengan baik/akurat akan menjadi patokan dalam mendiagnosis masalah personal hygiene pada pasien.

Dalam pengkajian ini hal - hal yang perlu dicari adalah tentang pola kebersihan pasien sehari -hari, sarana dan prasarana yang dimiliki dan faktor yang mempengaruhi personal hygiene pasien baik itu faktor yang mendukung masalah maupun faktor yang menjadi dasr timbulnya masalah pada personal hyginene pasien. Setelah melakukan ini maka tindak selanjtnya adalah melakukan pemeriksaan fisik.

\section{Penetapan Diagnosis}

Diagnosis keperawatan umum untuk pasien dengan masalah personal hygiene adalah defisit perawatan diri. Diagnosis tersebut dibagi menjadi empat yaitu defisit perawatan diri : makan, defisit perawatan diri : mandi/hygiene, defisit perawatan diri : berpakaian/berhias, defisit perawatan diri :eliminasi, dan diagnosis umum lain yang muncul yaitu gangguan interitas kulit dan gangguan citra tubuh (Kozier, 2004).

\section{Perencanaan dan Implementasi}

Menyusun rencana keperawatan untuk pasien yang membutuhkan perawatan diri harus mempertimbangkan kondisi pasien termasuk status emosional yang dimiliki pasien, sumber daya ekonomi, dan kemampuan fisik pasien. Perawatan yang akan dilakukan harus terlebih dahulu membina hubungan yang baik 
dengan pasien untuk membantu perawat dalam praktik membantu personal hygiene pada pasien, karena beberapa pasien sangat sensitif mengenai personal hygienenya. Selain perawat keluarga pasien juga bisa turut membantu dalam pemenuhan personal hygiene pasien bila dibutuhkan/pasien lebih nyaman bila keluarganya yang membantunya dalam melakukan perawatan dirinya.

Rencana asuhan keperawatan untuk pasien dengan masalah personal hyginene harus mempertimbangkan hal - hal yang disukai pasien, kesehatan pasien dan keterbatasan yang dimiliki pasien. Selain itu, perawat juga perlu memperhatikan waktu yang tepat dalam memberikan asuhan keperawatan serta fasilitas dan tenaga yang tersedia.

\section{Evaluasi}

Evaluasi yang harus diperhatikan oleh perawat setelah melakukan asuhan keperawatan pada pasien dengan masalah personal hygiene yaitu:

1. Melihat kembali perkembangan kesehatan pasien

2. Hasil yang diharapkan dari perawatan personal hygiene yang diberikan oleh perawat tidak dapat dilihat dalam jangka pendek (dalam beberapa hari).

3. Perawatan/pembersihan harus sering dilakukan untuk hasil yang diinginkan.

4. Perawat harus dapat mengantisipasi kebutuhan untuk mengubah intervensi selama evaluasi.

\section{PENUTUP}

Dalam masa pengobatan pasien salah satu faktor pendukung yang membantu mendukung peningkatan kesehatan pasien adalah personal hygiene yang baik pada pasien. Pada beberapa kasus pasien memiliki masalah pada personal hygienenya yang disebabkan oleh faktor pengetahuan dan juga faktor pendukung lainnya, dalam hal ini perawat bertanggungjawab dalam memberikan asuhan keperawatan kepada pasien sesuai dengan proses keperawatan dengan harapan dapat membantu pasien untuk meningkatkan derajat kesehatannya. Selain itu perawat juga dituntut dapat menyesuaikan perawatan dan memperhatikan hal - hal yang dapt dilakukan dan tidak sehingga asuhan keperawatan yang akan dilakukan dapat membuat pasien merasa nyaman. 


\section{REFERENSI}

Andriani, D. 2016. Gambaran persepsi pasien tentang pelaksanaan pemenuhan kebutuhan personal hygiene oleh perawat di RSUD ungaran Semarang Tahun 2016 (Skripsi). Semarang. Universitas Diponegoro.

Andani, I. K. 2016. Gambaran Perawatan Personal Hygiene pada Klien Penyakit Kusta di Puskesmas Padas Kabupaten Ngawi (Skripsi). Surakarta. Universitas Muhammadiyah Surakarta.

Damanik, S. M., dkk. 2011. Kepatuhan Hand Hygiene di Rumah Sakit Immanuel Bandung (Tesis). Bandung. Universitas Padjajaran.

Ernawati, E., dkk. 2014. Penerapan Hand Hygiene Perawat di Ruang Rawat Inap Rumah Sakit (Jurnal Kedokteran Brawijaya), Vol.28, Suplemen No. 1. 2014.

Laily \& Sulistyo. 2012. Personal Hygiene : Konsep, Proses, dan Aplikasi dalam Praktik Keperawatan. Yogyakarta : Graha Ilmu.

Mubarak, W. I., Indrawati, L., Susanto, J. 2015. Buku Ajar Ilmu Keperawatan Dasar. Jakarta : Salemba Medika.
Permatasari, D., Rohimah, S., Romlah. 2019. Gambaran Kepuasan Keluarga Pasien Stroke pada Pemenuhan Personal Hygiene oleh Perawat di Ruang Mawar RSUD Kabupaten Ciamis Tahun 2018 (Jurnal Keperawatan), Vol. 1, No. 2 Tahun 2019.

Potter \& Perry. 2005. Buku Ajar Fundamental Keperawatan ; Konsep, Proses, dan Praktik Edisi 4. Jakarta : EGC.

Potter \& Perry. 2010. Fundamental of Nursing (fundamental Keperawatan). Buku 1. Edisi 7. Indonesia : Salemba Medika.

Potter \& Perry. 2010. Fundamental of Nursing (fundamental Keperawatan). Buku 2. Edisi 7. Indonesia : Salemba Medika.

Potter \& Perry. 2010. Fundamental of Nursing (fundamental Keperawatan). Buku 3. Edisi 7. Indonesia : Salemba Medika.

Simamora, R. H. (2019). Menjadi Perawat yang : CIH' HUY. Surakarta. Kekata publisher.

Sulistyowati, D., Handayani, F. 2012. Peran Perawat dalam Pelaksanaan Personal Hygiene Menurut Persepsi Pasien Mobilisasi Fisik (Jurnal 
Keperawatan), Vol. 1, No. 1 Tahun 2012, Hal. 169 - 174.

Tarwoto \& Wartonah. 2012. Kebutuhan

Dasar Manusia dan Proses

Keperawatan. Jakarta : Salemba

Medika.

Zara, N. C. 2016. Asuhan Keperawatan

Pemenuhan Kebutuhan Personal

Hygiene pada Nn. $N$ di Ruang Dahlia RSUD Dr.Soedirman Kebumen (Jurnal Keperawatan), Vol. 2, No. 1 Tahun 2016, Hal. 87 - 90.

Zendrato, S. A. (2019). Memberikan proses keperawatan dalam melakukan perawatan klien. osf.io. 